\title{
Eğitimi Gerçekleştirmek: Öğretim Programlarında Okul Kütüphanelerinin Yeri
}

\author{
Realizing the Education: School Libraries in Curriculum \\ Programs
}

\author{
Inci ÖNAL ve Özlem ŞENYURT TOPÇU*
}

\begin{abstract}
Öz
Çalışmamız, Türkiye'de eğitim sistemi içinde yer alan öğretim programlarının öğrencileri okul kütüphanelerini kullanmaya nasıl yönlendirdiğini ortaya çıkarmayı amaçlamaktadır. Bu kapsamda 2012 Mayıs ve 2013 Şubat tarihleri arasında Milli Eğitim Bakanlığı Talim Terbiye Kurulu Başkanlığı tarafından hazırlanan öğretim programlarından 30 ilköğretim programı saptanmıştır. Illköğretim programlarında kütüphane kullanımı, okuma ve araştırmaya yönlendirici ifadelerin olup olmadığı her programın öncelikle amaç, kapsam, vizyon ve yöntem daha sonra kazanım ve etkinlikler kısımlarından ayrıntılı olarak incelenmiştir. 30 ilköğretim programı değerlendirildiğinde yukarıda belirtilen kısımlarda kütüphane kullanımı, okuma ve araştırmaya yönlendirici ifadeler olmasına karşın, her ders için dengeli ve yeterli bir dağııım bulunmadığı vurgulanmıştır.
\end{abstract} Türkiye

Anahtar sözcükler: Okul kütüphaneleri, Öğretim programları, ilköğretim, Eğitim sistemi,

\begin{abstract}
This study aims to determine the role of curriculum programs in Turkish education system on how students are encouraged to use school libraries. In this framework 30 primary curriculum programs in the context of the Ministry of National Education, the Board of Education and Discipline, were analyzed between May 2012 and February 2013. It was examined whether expressions leaning towards use of libraries, reading and research existed initially in the objective, scope, vision, method and then within context of gain and efficiency of these curriculum programs. In the event the result of these analysis were affirmative - that expressions entailing use of libraries, reading and making research were observed in the mentioned sections - it was concluded that an equal and adequate allocation had not been in question for each lesson.
\end{abstract}

Keywords: School libraries, Curriculum programs, Primary education, Education system, Turkey

* Prof.Dr., Hacettepe Üniversitesi, Bilgi ve Belge Yönetimi Bölümü, Beytepe, Ankara. (onal@hacettepe.edu.tr)

** Arş.Gör., Hacettepe Üniversitesi, Bilgi ve Belge Yönetimi Bölümü, Beytepe, Ankara. (ozlemsenyurt@hacettepe.edu.tr) 


\section{Giriş}

Eğitim hayat boyu yaşamakta olduğumuz, ancak her aşamasını fark etmekte ve hatırlamakta güçlük çektiğimiz uzun bir süreçtir. Yaşamını sürdürmek için insan eğitimsiz yaşayamaz. Solunum, beslenme, tutunma gibi temel davranışların dışında insan öğrendiği her ortamda başkalarınca eğitiliyor demektir. Toplumsal hizmet olması nedeniyle devlet, eğitim hizmetlerini topluma sunmakla yükümlüdür. Eğitim sistemi ve okullar bu hizmeti halka sunmak için kurulmuşlardır. Genellikle örgün ve yaygın eğitim kurumlarında resmi olarak belli öğretim programları çerçevesinde alınan eğitim zihnimizde yer etmekte, bir sonraki eğitim aşamasını izlememizi sağlamakta ve hayatımızı etkilemektedir. Ulusal eğitim sistemleri kapsamında hazırlanan öğretim programları yardımıyla, ülkeler vatandaşlarına kazandırmayı hedefledikleri bilgi, beceri ve yetenekleri somut olarak belirlemektedirler. Hazırlanan öğretim programları aracılığıyla, önceden belli olan program izlenerek hedeflenen amaçlar gerçekleştirilmeye çalışılmaktadır. Ülkeler, öğretim programlarında öğrencileri okuma ve kütüphane kullanma alışkanlığına sahip bireyler olarak yetişmelerini sağlamakla kalmayıp, onları araştırma yapmaya özendirecek faaliyetleri de desteklemektedirler. Eğitim ortamlarında yeniden yapılanmanın gündemde olması, ulusal eğitim sistemlerinin geliştirilmesinde öğretim programlarının önemini ortaya çıkarmaktadır. Hayat sürdükçe yaşam boyu eğitimin sürdüğü bilinen gerçek olarak kabul edilmektedir.

Bu çalışmada, Türk milli eğitim sistemi temel alınmıştır. Türkiye'de Milli Eğitim Bakanlığı Talim Terbiye Kurulu Başkanlığı tarafından hazırlanan 2012-2013 yıllarına ait 30 ilköğretim programı incelenmiştir. Temel eğitim olarak da adlandırılan birinci sınıftan, sekizinci sınıfa değin, her sınıfa yönelik öğretim programları ele alınmıştır. Her bir ilköğretim programında, amaç, kapsam, vizyon, yöntem, kazandırılması beklenen beceriler ve etkinlikler kısmı değerlendirilerek, bunların okul kütüphanesi kullanımıyla bağlantısı olup olmadığını saptamak ve öğretim programlarında gerçekleştirilecek yeni çalışmalara katkı sağlamak amaçlanmıştır. Bu kapsamda, 30 ilköğretim programının içeriğine bakılarak öğrencilerin okuma, çeşitli bilgi kaynaklarını kullanma, okul kütüphanesinden yararlanma ve araştırma yapmaya yönlendirme konularına ne kadar önem verdikleri değerlendirilmiş ve sonuçlar ortaya çıkarılmıştır.

\section{Eğitim Nedir?}

Eğitim, önceleri Arapça "terbiye" olarak kullanılan, 1940'lardan bu yana dilimize yerleşen bir terimdir. Eğitim en yaygın biçimde "herhangi bir varlığı bir amaca göre geliştirip, yetiştirme" (Hançerlioğlu, 1982, s.79) ve "bireyin davranışında kendi yaşantısı yoluyla ve kasıtlı olarak istendik değişme meydana getirme süreci" (Ertürk, 1997, s.12) tanımlarıyla ifade edilmiştir. Eğitim üzerine yapılan tanımlar bireyin mevcut koşullar içinde ve geleceğe hazırlanırken gerekli bilgi, beceri, yeterlilik, anlayış ve yeteneklere sahip olması ve/veya bu yeteneklerin ortaya çıkarılmakla kalınmayıp, geliştirilmesi süreçlerinin toplamını ifade etmiştir (Yılmaz, 2004, s.50; Filiz, 2006, s. 4-5). 
Bu tanımlardan anlaşılacağı gibi eğitim, eğitilmekte olan bireyin ve toplumun planlanmış süreci izlemesini ve yaşamasını hedefler. İstenilen davranışı kazandırmakla kalmaz, sonsuz gelişmelere yol açar. Yetişecek yeni nesli geleceğe hazırlar ve ortak değerler oluşturur.

\section{Türk Milli Eğitim Sistemi}

Türk milli eğitim sisteminin genel çerçevesini 1973 tarih ve 1739 sayılı Milli Eğitim Bakanlığı Milli Eğitim Temel Kanunu belirlemektedir. Bu Kanun, Türk milli eğitim sisteminin düzenlenmesinde esas olan "amaç ve ilkeler; eğitim sisteminin genel yapısı; öğretmenlik mesleği; okul binaları ve tesisleri; eğitim araç ve gereçleri; eğitim ve öğretim alanındaki görev ve sorumluluk; son hükümler" (Milli Eğitim Temel Kanunu, 1973) ile ilgili konu başlıklarına dair hükümleri bir sistem bütünlüğü içinde kapsamaktadır.

Milli Eğitim Temel Kanunu'nda 1983'de yapılan değişiklikle, Türk milli eğitiminin genel amaçları: Atatürk ilke ve inkılâplarını benimseyen, bilimsel düşünme şeklini esas alan, ilgi ve yetenekleri dâhilinde kendini yetiştirip geleceğe hazırlayan ve nihayetinde toplumun ilerlemesine ve ekonomik kalkınmaya katkı sağlayan yararlı bireyler yetiştirmek olarak belirlenmiştir. (Milli Eğitim Temel Kanunu, 1973; Milli Eğitim Temel Kanunu, 1983).

\section{Temel illkeler}

Türk milli eğitim sisteminin gerçekleştirmek istediği temel ilkeler aşağıda yer alan 14 başlık altında toplanmıştır (Milli Eğitim Temel Kanunu, 1973):

1. Genellik ve eşitlik,

2. Ferdin ve toplumun ihtiyaçları,

3. Yöneltme,

4. Eğitim hakkı,

5. Fırsat ve imkân eşitliği,

6. Süreklilik,

7. Atatürk inkılâp ve ilkeleri ve Atatürk milliyetçiliği,

8. Demokrasi eğitimi,

9. Lâiklik,

10. Bilimsellik,

11. Plânlılık,

12. Karma eğitim,

13. Okul ile ailenin iş birliği,

14. Her yerde eğitim. 
Temel ilkelerden bilimsellik ilkesine baktığımızda, "eğitimde verimliliğin artırılması ve sürekli olarak gelişme ve yenileşmenin sağlanması bilimsel araştırma ve değerlendirmelere dayalı olarak yapılır" (Milli Eğitim Temel Kanunu, 1973) sözleriyle araştırma yapmaya verilen önem yansıtılmaktadır. Bilimsel araştırma yapabilmek ve gelişmeleri takip edebilmek için gerekli kaynakların sağlanması, doğru ve güvenilir bilginin elde edilmesi kütüphane kurumuna olan gereksinimi ortaya koymuştur.

\section{Türk Milli Eğitim Sisteminin Genel Yapısı}

Türkiye'de eğitimin yapısı örgün ve yaygın eğitim olmak üzere ikiye ayrılmaktadır. Konumuz kapsamında ele aldığımız eğitim programları örgün eğitim yapısı içine girmektedir.

Örgün eğitim planlı, programlı, okulda gerçekleştirilen, amaç ve hedeflerini milli eğitimin belirlediği eğitimdir (Fidan ve Erden, 1993, s. 24). Örgün eğitim kurumları; okul öncesi eğitim, ilköğretim, ortaöğretim ve yükseköğretimden oluşmaktadır. Bu araştırmada örgün eğitim kapsamında yer alan ilköğretim programları incelenmektedir.

\section{Illköğretim Kurumları}

1997 yılında "Sekiz Yıllık Zorunlu Eğitim Kanunu" çıkarılmasıyla ilkokul ve ortaokullar birleştirilerek ilköğretim okulları haline getirilmiştir. Ancak, 2012 yılında Milli Eğitim Temel Kanunu kapsamında 24 ve 25 'nci maddelere yönelik yapılan değişiklikle, “ilköğretim kurumları; dört yıl süreli ve zorunlu ilkokullar ile dört yıl süreli, zorunlu ve farklı programlar arasında tercihe imkân veren ortaokullar ile imam-hatip ortaokullarından oluşur" denmiştir (Milli Eğitim Temel Kanunu, 1973; Milli Eğitim Temel Kanunu, 2012).

Milli Eğitim Bakanlığı İlköğretim ve Eğitim Kanunu'nun birinci maddesinde ilköğretimin amacı"kadın erkek bütün Türklerin milli gayelere uygun olarak bedeni, zihni ve ahlaki gelişmelerine ve yetişmelerine hizmet eden temel eğitim ve öğretim" olarak belirlenmiştir (Illköğretim ve Eğitim Kanunu, 1961). Bu kanunun üçüncü maddesinde 2012 yılında yapılan değişiklik, "mecburi ilköğretim çağı 6-13 yaş grubundaki çocukları kapsar ve bu çağ çocuğun 5 yaşını bitirdiği yılın eylül ayı sonunda başlar, 13 yaşını bitirip 14 yaşına girdiği yılın öğretim yılı sonunda biter" ifadesiyle yer almıştır (Illköğretim ve Eğitim Kanunu, 1961; İlköğretim ve Eğitim Kanunu, 2012).

İlköğretim kurumları yönetmeliğinin geniş kapsamlı amaçları arasında, ilköğretimin bilgiye ve okumaya yönelik temel amaçlarını kısaca şöyle sıralayabiliriz (Illköğretim Kurumları Yönetmeliği, 2003):

$\diamond \quad$ Öğrencilerin en iyi şekilde yetiştirilerek hem bireysel hem toplumsal açıdan faydalı kişiler olmalarını sağlamak.

$\diamond \quad$ Bunu yaparken sosyal, kültürel, teknolojik ve sanatsal açıdan yeterli bilgiye sahip bireyler yetiştirmek. 
$\diamond$ Gereksinim duyulan bilgiyi elde etme ve kullanma yeterliliklerini öğretecek programları desteklemek.

$\diamond$ Öğrencilere okuma alışkanlığı kazandırmak.

Günümüz bilgi çağı sayılmakla birlikte, sadece bilgi kullanımını yaşamın her aşamasına uygulayabilen gelişmiş toplumlar bilgi toplumu olarak nitelendirilmektedir. İletişim teknolojilerindeki hızlı gelişme ve çağın gereksinimlerine uygun nitelikte insan yetiştirebilmek ancak eğitim aracılığıyla gerçekleştirilebilirken, yaşam boyu sürecek olan bu etkinliğin ilk ve en önemli adımı ilköğretimlerdir. Bu nedenledir ki, okuma, araştırma ve kendi kendine öğrenmeyi başarabilmek "temel eğitim" olarak nitelendirilen eğitimin bu ilk basamağında kazandırılmaktadır. Erken yaşlarda eğitim aracılığıyla edinilebilecek bu kazanımlar bireysel ve toplumsal olarak eğitimde amaçlanan hedeflere temel teşkil edecektir.

\section{Eğitim ve Öğretim Programları}

Çoğu zaman birbirinin yerine kullanılan eğitim programı ve öğretim programı kavramlarına ilişkin şu tanımlar yapılmaktadır.

Eğitim programı, "bireyde istenilen yönde davranış değişikliği meydana getirmek amacıyla yapılan tüm faaliyetleri gösteren plan" (Fidan ve Erden, 1993, s.73) olarak kabul edilmektedir. Ertürk (1982, s.95) "yetişek" olarak nitelendirdiği müfredat veya öğretim programını "geçerli öğrenme yaşantıları düzeni" olarak tanımlarken, belirli esaslara göre düzenlenip örgütlenen öğrenme yaşantısının öğretim programının tasarımını meydana getirdiğini ifade etmiştir. Demirel (2005, s.4-6) eğitim programını, "öğrenene okulda ve okul dışında planlanmış etkinlikler yoluyla sağlanan öğrenme yaşantıları düzeneği", öğretim programını ise, "okul ya da okul dışında bireye kazandırılması planlanan bir dersin öğretimiyle ilgili tüm etkinlikleri kapsayan yaşantılar düzeneği" olarak tanımlamıştır. Öğretim programı "belli bir öğrenim basamağındaki sınıflarda okutulacak derslerin, amaçlarını, içeriğini (konusunu), eğitim yaşantılarını ve değerlendirme süreçlerini kapsamaktadır" (Filiz, 2006, s.14). Dengiz (2006, s.24), yaptığı tanımla öğretim programlarının ilgili ülkeye ait "eğitim sisteminin temelini ve genel yapısını" gösterdiğini belirtmektedir.

\section{Okul Kütüphanesi}

IFLA/UNESCO (t.y., s.1) tarafından hazırlanan Okul Kütüphanesi Bildirgesi'nde okul kütüphanesi, "günümüzün bilgiyi temel alan toplumunda başarılı hizmetlerin verilmesi için esas olan bilgi ve düşünceleri" kapsar. Okul kütüphanesi "öğrencilerin sorumlu vatandaşlar olarak yaşamalarını sağlarken, onları yaşam boyu öğrenme becerisiyle donatır ve hayal güçlerini geliştirir" şeklinde ifade edilmiştir (IFLA/UNESCO, t.y., s.1). Bildirge okul kütüphanesini eğitimin ayrılmaz bir parçası olarak belirtirken amaçları kısaca şöyle sıralamaktadır (IFLA/UNESCO, t.y., s.2): 
$\diamond \quad$ Okul programlarını desteklemek;

$\diamond$ Okuma ve kütüphane kullanma alışkanlığı kazandırmak;

$\diamond$ Bilgiye erişme ve elde edebilme becerisini sağlamak;

$\checkmark$ Araştıran, okuyan, üreten bireyler yetiştirmek;

$\diamond$ Okul, öğrenci, öğretmen ve veliler arasında işbirliğini sağlamak;

$\diamond$ Okul-kütüphane arasındaki ilişkiyi ilgili tüm tarafların kavramasına yardımcı olmak.

Eğitim ortamlarında bilgi kaynaklarının, araçlarının ve iletişim teknolojilerinin hızı gelişimiyle birlikte okul kütüphaneleri medya merkezi niteliği kazanmış ve bu doğrultuda görevleri artmıştır. Bilginin yayınlandığı biçime bağlı sağlama sınırlaması getirilmeksizin, özellikle bilgiye önem verilmiştir. Görev ve sorumlulukların kapsamına şunlar girmektedir (Fasick, 2011; Marquardt ve Oberg, 2011; Önal, 2012; Woolls, 2008):

$\diamond$ Öğrencilerin, öğretmenlerin ve çalışanların etkin fikir ve bilgi kullanıcıları olmalarını sağlamak;

$\diamond$ Öğrenciler başta olmak üzere, kullanıııları bilgiyi sorgulama, eleştirel düşünme ve bilgi edinme konularında eğitmek;

$\diamond$ Kullanıııları sonuç çıkarma, mantıklı kararlar alma, bilgiyi yeni durumlara uygulama, yeni bilgi yaratma konularında yönlendirmek;

$\checkmark$ Sahip olunan bilgiyi paylaşma isteği kazandırmak;

$\diamond$ Etik değerler çerçevesinde bilgi üreticisi olarak topluma katkıda bulunmaya teşvik etmek;

$\diamond \quad$ Her bir öğrencinin bilgi gereksinimlerini karşılama amacıyla öğrenme stratejileri tasarlamak için öğretmenlerle ve yöneticilerle birlikte çalısmak;

$\diamond$ Kişisel ve toplumsal estetik gelişimi destekleyecek ortamlarda hizmet sunma yoluyla yapıcı değerler oluşturmak.

Okul kütüphaneleri eğitim faaliyetlerini, yaşam boyu öğrenme etkinliklerini ve kişisel gelişimi destekler. Bilgi kaynaklarına erişme imkânı sağlamanın yanı sıra okuma alışkanlığı kazandıır ve okumanın kazanımlarını benimsetir. Ayrıca okul kütüphaneleri sahip oldukları hizmet felsefesi desteğiyle "bulunulan ülkenin eğitim, öğretim, yayıncllık ve kütüphanecilik ile ilgili yasal yaptırımlarıyla sürekli etkileşim halindedir" (Önal, 1992, s.64).

Osmanlı Devleti'nden itibaren günümüz Türkiye'sine değin ilk ve orta öğretim düzeylerindeki okul kütüphaneleri tarihi 16.yüzyıldaki cami okullarına dayanmaktadır. Kurulmaları zorunludur, ancak eğitimde aktif olmalarını sağlayacak yaptırımlar hazırlanmamıştır. Bu kütüphaneler, yüksek öğretim kurumları olan medrese ve enderun okullarında bulunan kütüphanelerden etkilenmeleriyle araştırmaya önem vermişlerdir. 1857 yılında Milli Eğitim Bakanlığı'nın kurulmasıyla Türk eğitim sistemi biçimlenmeye başlamıştır. 1920'lerde Cumhuriyet Döneminin başlamasının ardından 3 Mart 1924 
tarihinde Tevhid-i Tedrisat Kanunu'nun (Türkiye Cumhuriyeti, 1924) çıkmasıyla eğitim ortamlarında, sistemlerinde ve öğretim programlarında birliksağlanmıştır. Derslere yönelik bütün öğretim programlarında okul kütüphaneleri yer almıştır. İlk, orta ve yüksek öğretim kurumları ülke çapında yaygınlaşırken her okulda "okul kütüphanesi" olarak adlandırılan bir yer ayrılmış veya okul kütüphaneleri sadece kurulmuş, etkin hizmetlerin verileceği gelişmeler sergilenememiştir. Türk milli eğitim sistemine yönelik gelişim önerilerini almak üzere yurt dışından 1952 tarihinde John Dewey ve Lawrence S. Thompson, 1956'da John Rufi olmak üzere önemli eğitimciler geldiklerinde okul kütüphanelerinin eğitim çalışmalarına aktif desteğinin olması gerektiğinden söz etmişlerdir. 1959, 1976, 2001 tarihlerinde yayınlanan Okul Kütüphaneleri Yönetmelikleri okul kütüphanelerinin amaçlarını, görevlerini ve temel çalışma ilkelerini vermiştir (Önal, 2005, s.142).

Türkiye'de okul kütüphanelerinin amaçları 24501 sayılı ve 2001 tarihli Okul Kütüphaneleri Yönetmeliği'nde şu şekilde ifade edilmiştir:

“Türk millî eğitiminin genel amaçları ve temel ilkeleri doğrultusunda öğrencilerin bilimsel düşünen, demokratik davranışlara sahip, okuma alışkanlığı kazanmış, öğrenmeye, araştırmaya ve yeni teknolojileri kullanmaya istekli; hak, görev ve sorumluluklarının bilincinde; çağın gereklerini yerine getirebilecek şekilde yetişmelerine ve yararlanmalarına yardımcı olmak için okul kütüphaneleri ile ilgili gerekli düzenlemeleri yapmaktır" (Okul Kütüphaneleri Yönetmeliği, 2001).

Bu amaçlar, okul kütüphanelerinin eğitim sistemi içindeki yerini açıkça ortaya koymakla kalmamaktadır. Ayrıca, eğitim faaliyetleriyle birlikte sunulan bilgi hizmetleriyle, okul kütüphanelerinin bireylerin yaşam boyu öğrenme faaliyetlerini olumlu yönde etkileyecek görevlerini de sürdüreceğini anlatmaktadır.

Okul kütüphaneleri sadece öğrencilerin değil "kullanıcı hizmetleri" aracılığıyla kütüphane dermesinden öğretmenlerin ve diğer personelin etkili biçimde yararlanmasını görev edinmektedir. "Danışma hizmeti" aracılığıyla da, gereksinim duyulan basılı ve elektronik ortamlardaki bilgiyi en kısa zamanda elde edilmesini hedeflemektedir (Okul Kütüphaneleri Yönetmeliği, 2001).

Türkiye'de okul kütüphanelerinin hizmet vermesinde karşılaşılan yaygın sorunlar öğretim programlarında okul kütüphanelerinin nasıl yer aldığına dair araştırma yapmamızın temel dayanağı olmuştur.

\section{Önceki Çalışmalar}

Eğitimin gerçekleştirmesi istenen amaç ve hedefleri öğretim programları aracılığıyla planlı bir şekilde okullarda gerçekleştirilir. Bulunulan öğretim kademesinde eğitimin amaçlarını yerine getirmek için kütüphaneler kurulur. Öğretim programlarında okul kütüphanelerine verilen yer, önem ve görevler ülkelerin gündeminden hiç düşmemiştir (Önal, 2009). Modern anlamdaki okul kütüphanelerinin 1920'lerden itibaren ülkelerin 
öğretim programlarında yer alarak başarılı hizmetlerin verilmesini sağlamak üzere bütün dünyaya yayıldığı anlaşılmaktadır (Callison, 1998; Önal, 2009).

Soysal (1969) Çağdaş eğitim ve Türkiye'de okul kütüphanesi adlı kitabında öğretim programlarının başarıyla gerçekleştirilmesinde okul kütüphanelerinin çok önemli katkılarının olacağına değinmiştir. Aynı yayında, Türkiye Cumhuriyeti'nin kuruluş yıllarından başlayarak ve yabancı uzmanların görüşlerini vererek öğretim programlarının gerçekleştirilmesinde aktif olarak yer alması gereken okul kütüphanelerine dair temel bilgiler sunulmuştur.

Önal (1992, s.89-92) doktora tez çalışmasıyla, lise öğretim programlarında öğrencilerin bilgi gereksinimleri ve bilgi gereksinimlerinin karşılanmasında kütüphanelere verilen önemi incelemiştir. Bu araştırma 1924 yılında ilk olarak hazırlanan lise öğretim programından başlayarak 1992 yılına değin gelişmelere yer vermiştir. Önal'ın önerilerine göre, öğretim programlarının kütüphane kullanımına yer vermesiyle "öğrenci odaklı olarak" belirli bilgileri aktarmak yerine bilgi kazanma yolları öğretilecek, ders konularıla ilgili bilgi kaynaklarına yöneltilecek ve ders dışı çalışmalar desteklenecektir.

Dengiz (2006) yüksek lisans tez çalışmasıyla, Ankara'daki 7 ilköğretim okulunda görev yapan 118 sınıf öğretmeninin okuma ve kütüphane kullanma alışkanlıkları açısından 2004 yılı ilköğretim programına ilişkin görüşlerini analiz etmiştir. Öğretmenlere göre, programlar sözü edilen alışkanlıkları kısmen içermektedir. Temel sorunun kütüphane yetersizliğinden kaynaklandığı belirtilmektedir.

Türkiye'de 2013 yılına ait son uygulamaları yansıtarak her derse ait ilköğretim programlarında öğrencileri çeşitli kaynaklara, kütüphanelere ve özellikle okul kütüphanesi kullandırmaya yönlendirme durumunu ayrıntılı olarak inceleyen araştırmaya henüz rastlanmamıştır.

\section{Araştırmanın Amacı, Kapsamı ve Yöntemi}

Bilginin sınırlarını zorlayarak her geçen gün büyük bir hızla arttığı ve yayıldığı günümüzde güvenilir bilgiye erişim problemi kütüphanelerin varlığını daha da önemli kılmaktadır. Bu noktada araştırmamız ilköğretim programlarını inceleyerek, öğrencileri çeşitli kaynaklara, kütüphanelere ve özellikle okul kütüphanesi kullandırmaya yönlendirme durumlarına ilişkin değerlendirmeler yapmaya çalışmıştır.

Bu araştırmanın amaçları:

$\diamond$ İlköğretim programında yer alan 30 öğretim programını amaç, kapsam, vizyon ve yöntem açılarından ayrıntılı olarak incelemek;

$\diamond$ İncelenmekte olduğumuz 30 ilköğretim programını kazandırılması beklenen beceriler ve etkinlikler konularındaki temel unsurlar kapsamında değerlendirmek;

$\diamond$ Öğretim programlarıyla ilgili gerçekleştirilecek yeni çalışmalara katkı sağlamaktır. 
Türk milli eğitim sisteminin temel alındığı araştırmamızın kapsamını Türkiye'de Milli Eğitim Bakanlığı Talim Terbiye Kurulu Başkanlığı tarafından hazırlanan 2012-2013 yıllarına ait 30 ilköğretim programı oluşturmaktadır. Araştırmada betimleme yöntemi uygulanmıştır.

\section{Bulgular ve Değerlendirme}

Milli Eğitim Bakanlığı Talim Terbiye Kurulu Başkanlığı web sitesinden elde edilen ilköğretim programları 2012 Mayıs ve 2013 Şubat tarihleri arası incelenmiştir. Eğitimde 4+4+4 olarak adlandırılan yeni bir sisteme geçilmiştir. 2013 Haziran ayında 1+3+4+4 olarak ilköğretimin birinci sınıfının ayrı düşünülebileceği ifade edilmiştir. Fakat öğretim programlarında ilköğretim programı adı ile yer aldığından temel eğitim programları bu isimle kullanılmaktadır.

Toplamda 30 ilköğretim programı incelenmekle birlikte bazı dersler sınıflara göre ayrıldığından tek öğretim programı olarak yazılmıştır. Öğretim programlarının amaç, kapsam, vizyon ve yöntem kısımları değerlendirilirken sınıf basamakları yazılarak bu ayrım belirtilmiştir. Ancak, tabloda bu ayrıma gidilmemiştir ve 25 ders olarak değerlendirilmiştir. Araştırmaya başlanılan tarih olan 2012 Mayıs ve araştırmanın bitirildiği 2013 Şubat tarihleri arasında bazı öğretim programlarında değişiklikler meydana gelmiştir. İlköğretim Hayat Bilgisi Dersi ismi, Hayat Bilgisi Dersi olarak değiştirilmiştir. Almanca, Fransızca ve Arapça dersleri 2013 yılında ilköğretim programlarında yer almamıştır.

Bu bölümde, 2012 Mayıs ve 2013 Şubat tarihleri arasında 1-8. sınıflara yönelik 30 ilköğretim programı her bir öğretim programının amacı, kapsamı, vizyonu, yöntemi, kazandırılmak istenen beceriler ve son olarak, etkinlikler açılarından incelenmiştir. İlköğretim programını oluşturan ders programları içerik olarak tek tek taranarak, ilgili programın okuma, araştırma, bilgi kaynakları ve kütüphaneye yönlendirici bir içeriğe sahip olup olmadığına dair bulgular saptanmış ve değerlendirilmiştir.

\section{Beden Eğitimi Dersi (1-8. sınıflar) Öğretim Programı}

Beden eğitimi dersi öğretim programı temelde bireylerin yaşamları boyunca devam ettirecekleri fiziksel, bilişsel, duygusal ve toplumsal gelişimlerine katkı sağlayacak fiziksel etkinlikleri yapmalarını ve sürdürmelerini amaç edinmiştir. Öğrencilerin eğitim etkinlikleri boyunca tüm sürece aktif olarak katılmaları ve bu süreç sonunda kendilerinde meydana gelecek değişiklikleri fark etmeleri yukarıda sözü edilen amaçların gerçekleşmesini sağlayacaktır. Bu nedenle hazırlanan programda etkinlikler öğrencinin öğrenme sürecinde aktif rol alması yani öğrenme sürecine her adımda dâhil olmasını sağlayacak şekilde düzenlenmelidir denmiştir (MEB, 2012a, s.6). 
Programla ulaşılması beklenen temel beceriler arasında "eleştirel düşünme, yaratıcı düşünme, problem çözme, karar verme, Türkçeyi doğru, etkili ve güzel kullanma, araştırma, iletişim, bilgi teknolojilerini kullanma, bilimin temel kavramlarını tanıma, estetik zevk kazanma" yer almaktadır. (MEB, 2012a, s.7-8).

Bu ders kapsamında, öğrenciye kazandırılmak istenen beceriler arasında yer alan araştırma ve bilgi teknolojilerini kullanma, ders kapsamında istenen araştırmaları çeşitli bilgi kaynaklarını kullanarak gerçekleştirme, bilgi teknolojileri aracılığıyla bilgiye erişme ve elde etme bulunmaktadır. Programda yer alan amaçlar kapsamında öğrenciye edindirilmesi beklenen tüm bu becerilerin yaşam boyu sürmesi hedeflenmektedir.

\section{Bilişim Teknolojileri Dersi (1-8. Sınıflar) Öğretim Programı}

Teknoloji alanında meydana gelen hızlı gelişmeler bilişim teknolojileri alanında da büyük önem kazanmaktadır. Özellikle eğitim ve öğrenme etkinlikleri alanında iletişim teknolojileri önemli bir katkı sağlamaktadır. Değişen bu koşullara uyum sağlayabilmek ve bu teknolojileri kullanabilecek yeterliliğe sahip olmak yaşam boyu devam edecek öğrenme etkinliklerini ve gelişimini sürdürebilmek için zorunlu bir ön koşul haline gelmektedir. Bilişim teknolojileri dersi aracılığıyla elde edilecek beceriler neticesinde öğrenciler yaşamda karşılaştıkları problemlere yönelik olarak bilişim teknolojilerinden faydalanacaklardır.

Bilişim teknolojileri dersi aracılığıyla elde edilen etik ve sosyal değerler sayesinde öğrenciler: "bilginin bütünlüğüne ve sahipliğine saygı duyar", "telif hakkı olan ve/veya herkese açık materyalleri kullanırken alıntı yaptığı yeri bildirir", "kaynağın bir telif hakkının ve sahipliğinin olduğunu anlar", "bir korsan yayını orijinalinden ayırt eden özellikleri (ürün ID - tanım numarası vb.) bilir", "korsan yayıncılığın ürün sahibine, ekonomiye ve topluma olumsuz etkilerini fark eder". Sayılan bu kazanımlar sayesinde öğrenciler bilgi ve bilgiye yönelik etik ve telif hakkı konularına karşı farkındalık geliştireceklerdir (MEB, 2012b, s.10-11).

\section{Din Kültürü ve Ahlâk Bilgisi Dersi (4-8. Sınıflar) Öğretim Programı}

İlköğretim programlarında yapılmaya başlanan değişikliklerle, öğrencilerin din ve ahlak ile ilgili doğru bilgi almaları ve Milli Eğitimin hedeflediği genel amaçların gerçekleşmesini sağlamak beklenmiştir (MEB, 2012c, s. 2).

Programda öğrencilerin, artan bilgi nedeniyle "kavramların anlaşılması, değerlerin oluşması ve becerilerin gelişmesi sağlanarak öğrenmeyi, öğrenmenin gerçekleşmesi ön planda tutulmuştur". Bu programda da kazandırılması beklenen beceriler arasında araştırma ve bilgi teknolojilerini kullanma yer almaktadır (MEB, 2012c, s. 11,21). 


\section{Düşünme Eğitimi Dersi (6-8. Sınıflar) Öğretim Programı}

Düşünme eğitimi programı teknolojik gelişmelerle beraber televizyon, bilgisayar, oyun vb. farklı alternatiflerle etrafı sanal bir dünyayla çevrilmiş çocukların, eğitim yoluyla kazanacakları düşünme becerisi sayesinde sorgulayan, düşünen bireyler haline gelmesi hedeflenmektedir (MEB, 2012d, s. 6).

Düşünen, sorgulayan bireyler olmanın tek yolu okumaktan geçmektedir. Doğru bir muhakeme yeteneği ancak elde ettiği faklı görüşteki bilgileri karşılaştırmakla mümkün olurken, bu durum bireylere eleştirel bir bakış açısı sağlayacaktır. Düşünmenin ham maddesi olan bilgi eğitim süreci içinde ve dışında, yaşam boyu sürdürmesi için kazandırılacak okuma becerisiyle mümkün olacaktır.

\section{Fen ve Teknoloji Dersi (4-5. ve 6-8. Sınıflar) Öğretim Programı}

Programın amacı, tüm öğrencilerin fen ve teknoloji okuryazarı olmalarını sağlamaktır. "Fen ve teknoloji okuryazarı bireyler, bilgiye ulaşmada ve kullanmada, problemleri çözmede, fen ve teknoloji ile ilgili sorunlar hakkında olası riskleri, yararları ve eldeki seçenekleri dikkate alarak karar vermede ve yeni bilgi üretmede daha etkin bireylerdir" (MEB, 2012e, s. 5).

Bilimsel alanda meydana gelen gelişmelerin takibi ve yeni bilgi üretilmesi sürecinde alana özgü yayın ve bilgilerin takibi bilgi kaynaklarının etkin bir şekilde kullanılabilmesi ile mümkün olacaktır. Bu noktada öğrenciler kütüphaneleri kullanabilen aktif kullanıcılar olmalıdır.

Bu programla, öğrencilere kazandırılmak istenen beceriler arasında, "araştırma, okuma ve tartışma aracılığıyla yeni bilgileri yapılandırma becerileri kazanmalarını sağlamak", "bilmeye ve anlamaya istekli olma, sorgulama, mantığa değer verme, eylemlerin sonuçlarını düşünme gibi bilimsel değerlere sahip olmaları" yer almaktadır (MEB, 2012e, s. 9). Sayılan becerilerle öğrenciler yaşam boyu sürecek araştırma isteği ve güncel bilgi edinme gereksinimi ve alışkanlığı kazanacaktır.

\section{Görsel Sanatlar Dersi (1-8. Sınıflar) Öğretim Programı ve Kılavuzu}

Görsel sanatlar dersinin amaçları bireysel ve toplumsal, algısal, estetik ve teknik amaçlar olarak dört gruba ayrılmıştır. Genel olarak program öğrenciye görsel ve estetik zevk kazandırmak; sanat eserlerini ve sanatçıları tanıtmak; alanla ilgili bilgi birikimine sahip olmak ve bilgiyi uygulamalara yansıtmayı sağlamak konularını kapsamaktadır. Sonuçta tüm bu unsurlarla ilgili farkındalığın artırılması amaçlanmaktadır (MEB, 2012f, s. 10-11).

Programın kazandırması beklenen becerileri arasında araştırma yapma ve bilgi teknolojilerini kullanma yer almaktadır. Görsel sanatlar dersi kapsamında belirlenen üç öğrenme alanı: 1-Görsel sanatlarda biçimlendirme, 2-Görsel sanat kültürü kazandırma ve 3-Müze bilinci oluşturma olarak ifade edilmiştir (MEB, 2012f, s. 12). Öğrencilerin 
program kapsamında görsel sanatlar alanında elde edecekleri bilgi ve beceri yanında yeni bilgi ve çözümler üretmeyi alışkanlık haline getirmeleri amaçlanmıştır. Böylece (MEB, 2012f, s. 14):

“Öğrenciler, bağımsız olarak öğrenmeyi, çeşitli araştırma teknikleriyle bilgiye ulaşmayı, değerlendirmeyi, sorgulamayı ve yorumlamayı hayatlarının bütün safhalarında bir alışkanlık hâline getirirler" düşüncesi benimsenmiştir.

\section{Halk Kültürü Dersi (6. 7. ve 8. Sınıf) Öğretim Programı ve Kılavuzu}

Halk kültürü dersi ile öğrenciler kendi kültür ve kültür ürünlerini tanımaları, dünyada var olan kültürleri öğrenmeleri ve kendi kültürlerine karşı farkındalığı artırmanın yanı sıra korumalarını da sağlamak amaçlanmıştır (MEB, 2012g, s. 5).

Program temel yaklaşımında bilginin toplumların erişeceği en büyük güç olduğu vurgulanmıştır. Bilgiyi elinde bulunduran, üreten ve kullanan toplumların büyük üstünlüğe sahip olduğu ifade edilmiştir. Eğitim sistemi bu noktada çağın koşullarına uygun niteliklere sahip bireylerin yetişmesini sağlayacağı vurgulanmıştır. Ayrıca, bu program ile öğrenciler, "gözlem, araştırma ve derleme yapmaya özendirilir" ifadesine yer verilmektedir. Halk kültürü dersi programı içinde araştırma ve bilgi teknolojilerini kullanma becerileri kazandırılması amaçlanan nitelikler arasında yer almaktadır (MEB, 2012g, s. 7-8,9).

\section{İköğretim Hayat Bilgisi Dersi (1-3. Sınıflar) Öğretim Programı}

Bu programla, bireylerin sosyal çevresiyle, kendisiyle barışık, yaşamında gereksinim duyduğu bilgiyi elde edebilen, gerekli bilgi ve beceri ile donanmış, değişime ayak uydurabilen, fen ve teknoloji alanında temel bilgilere sahip olmaları amaçlanmıştır (MEB, 2012h, s. 9,11).

Kazandırılması istenen beceriler arasında araştırma, bilgi teknolojilerini kullanma ve Türkçeyi doğru, etkili ve güzel kullanma yer almaktadır. Araştırma becerisi ile soru sorma, gözlem yapma, veri toplama, araştırma sonuçlarını sunma vb. gibi aşamaları bilmeleri beklenir. Bilgi teknolojileriyle ise, öğrencilerin farklı kaynaklardan toplanmış bilgiyi kaydetme, biçimlendirme, tekrar kullanma, biçimlendirdiği bilgiyi sunma, telefonu ve televizyonu kullanarak bilgiye ulaşma, bilgiyi bulma, bilgiyi kullanılabilir biçimde planlama, kütüphaneden ve yazılı kaynaklardan yararlanma, toplumdaki bilgi kaynaklarını kullanma, bilgiye ulaşabilmek için gerekli her türlü kaynağı, araç ve gereci kullanması istenmektedir. Araştıran, okuyan birey doğal olarak Türkçeyi doğru ve etkili kullanacaktır. Bu becerilerle Türkçeyi doğru kullanma, anlaşılabilir bir biçimde konuşma ve yazma, doğru anlayıp anlamadığını kontrol etme, okunaklı bir şekilde yazma aşamalarının da gerçekleşmesi mümkün olacaktır (MEB, 2012h, s. 18-19). 


\section{İngilizce Dersi (4-8. Sınıflar) Öğretim Programı ile Seçmeli İng. Dersi Öğretim Programı}

Programın amacı, öğrencilerin anadili dışında başka bir dil daha öğrenmelerini sağlamaktır. Yaş düzeylerine göre dil öğrenme becerileri dikkate alınarak, etkinlik programları ona göre oluşturulmuştur (MEB, 2012i). Belirtilen kapsamda okuma programlarının yer alacağı genel olarak ifade edilmektedir.

\section{Matematik Dersi (1-5. ve 6-8. Sınıflar) Öğretim Programı}

Bu program öğrencilerin matematikle ilgili işlem ve kavramları öğrenmeleri için uygun öğrenme-öğretme ortamları yaratarak, öğrencilerin bağımsız düşünebilme ve karar verebilme, öz düzenleme gibi bireysel yetenek ve becerilerini geliştirmeyi amaçlamıştır. Programda ayrıca, öğrencilerin araştırma yapabilecekleri, keşfedebilecekleri, problem çözebilecekleri, çözüm ve yaklaşımlarını paylaşıp tartışabilecekleri ortamların oluşturulması programın temel yaklaşımları arasındadır (MEB, 2012j, s.8). Programda kazandırılması beklenen beceriler arasında araştırma ve bilgi teknolojilerini kullanma yer almaktadır.

\section{Medya Okuryazarlığı Dersi Öğretim Programı ve Kılavuzu}

Günümüz bilgi çağı olarak adlandırılmakta ve kitle iletişim araçlarında hızlı bir artış gözlenmektedir. Çeşitli iletişim kanalları yoluyla her gün yoğun bilgi bombardımanı içinde savunmasız kaldıkları düşünülerek öğrencilere yönelik programlar geliştirilmiştir. Medya Okuryazarlığı Dersi Öğretim Programı ve Kılavuzu aracılığıyla çocukların "gerçeklik" ve "kurgu" arasındaki farkı ayırt etmeleri, medya aracılığıyla elde edilen her bilginin doğru olmadığı, yanlı olabileceği gibi konularda farkındalık kazanmalarına çalışılmaktadır (MEB, 2012k, s.4-5).

\section{Müzik Dersi (1-8. Sınıflar) Öğretim Programı}

Bu programda, müzik öğretimi yanında, psikolojik ve sosyal açıdan dengeli, duygu ve düşünce dünyası gelişmiş, yaratıcı, sağlıklı, kendine güvenli bireyler yetiştirmek amaçlanmaktadır.

Programda kazandırılması hedeflenen temel beceriler arasında; "Türkçeyi doğru, güzel ve etkili kullanma, eleştirel düşünme, yaratıcı düşünme, iletişim kurma, problem çözme, araştırma, bilgi teknolojilerini kullanma, girişimcilik, müziksel algılama ve bilgilenme, kişisel ve sosyal değerlere önem verme, müzik okuryazarlığı edinebilme, estetik duyarlığa sahip olma" gibi nitelikler yer almaktadır (MEB, 2012l, s.7). 


\section{Sanat Etkinlikleri Dersi (1-8. Sınıflar) Öğretim Programı}

Bu programla öğrenciler sanat, sanat dalları ve etkinliklerini öğrenir. Sonuç olarak dersi alan öğrencilerin sanat dallarına ilişkin elde ettikleri bilgilerle yaşama "farklı yaklaşımlar getirebilen, farklı sanatsal dillerle kendilerini ifade edebilen, düşünen, üreten bireyler olmaları beklenmektedir" (MEB, 2012m, s.1-2).

Sınıfta uygulanacak sözel zekânın geliştirilmesine yönelik etkinlikler arasında hikâye ve dergi okuma, yazma, araştırma yer almaktadır. Drama ve tiyatro aracılığıyla kazandırılması beklenen beceriler arasında eleştirel düşünme, araştırma, Türkçeyi doğru, güzel ve etkili kullanma bulunmaktadır (MEB, 2012m, s.9, 17-18).

Sanat öğretimi ve etkinlikleri aracılığıyla çağdaş, kendi değerlerine saygılı nesiller yetiştirmek amaçlanmıştır. Bu sayede estetik duyarlılığa sahip, bilimden, sanattan, teknolojiden yararlanmasını bilen, kendisi de bilgi üreten, yaratıcı düşünceye sahip aydın insanlar yetiştirilmeye çalışılmaktadır. Ayrıca program kapsamında bir eğitim ortamı olarak müze kültürü verilmektedir. Müze eğitiminin hedefleri arasında, öğrencinin bilgiyi kendi kendine araştırıp geliştirmesine olanak sağlamak üzere bilim müzelerine yönlendirmek de yer almaktadır (MEB, 2012m, s.9, 20-21).

\section{Satranç Dersi (1-8. Sınıflar) Öğretim Programı}

Satranç programıyla öğrencilere, satranç öğretiminin yanı sıra temelde kazandırılmak istenen "bireyin zihinsel ve duyuşsal çok yönlü gelişimine yardımcı olmak" sözleriyle ifade edilmiştir. Bu noktada program ile: Çok yönlü, yaratıcı ve eleştirel düşünebilen, araştırma becerisi gelişmiş, günlük yaşamla birlikte öğrenebilen ve öğrendiklerini günlük yaşamda kullanabilen, akademik beceriler bakımından ileri seviyeyi yakalayan, beyin kapasitesini geliştirip en üst düzeyde kullanabilen" bireyleri yetiştirmek programın hedefleri arasındadır (MEB, 2012n, s.9).

Satranç dersi eğitimi aracılığıyla gerçekleştirilmesi beklenen bu üst düzey becerileri alanımız açısından düşündüğümüzde araştıran, kendini geliştiren, sorgulayan, düşünen bireylerin okuma ile bireysel gelişimlerini gittikçe artıracaklarını söylemek mümkün olacaktır.

\section{Sosyal Bilgiler Dersi (4-5. ve 6-7. Sınıflar) Öğretim Programı ve Kılavuzu}

Bilgiyi üreten ve kullanan toplumlar eğitim aracılığıyla nitelikli iş gücünü yaratabilmek için gerekli becerilerle donatılmış bireyler yetiştirmeye çalışmaktadırlar. Bu program, "bilgi, kavram, değer ve becerilerin gelişmesini sağlayarak, öğrenmeyi öğrenmenin gerçekleşmesini ön planda" tutmaktadır (MEB, 20120, s.1). 
Dersin genel amaçlarında 7. sınıf sonunda öğrencilerin bilimsel bilgiye ulaşmada, kullanmada ve üretmede bilimsel ahlak ve düşünme yöntemini göz önünde bulundururken, araştırma, bilgi ve iletişim teknolojilerini de kullanmaları beklenir. Araştırma becerisi kapsamında okuduğunu anlama ve bilgiyi bulma, kullanılabilir biçimde planlama ve yazma yer almaktadır. Bu kapsamda öğrencilerin kütüphaneyi kullanma, uygun bilgi kaynağından yararlanma ve bilgiyi uygun bir şekilde kaynakça, dipnot ve atıflar vererek yazma gibi becerileri elde etmesi beklenmektedir. Öğrencilerin gereksinim duyduğu bilgiyi, nerede, nasıl ve ne şekilde kullanabileceğine ilişkin bilgiler verilmesiyle bilgi-okuryazarlığı becerileri kazandırılacaktır (MEB, 2012o, s.4-5).

\section{Spor Etkinlikleri Dersi (1-8. Sınıflar) Öğretim Programı}

Spor etkinlikleri dersi aracılığıyla öğrencilerin spor okur-yazarı olmaları hedeflenmektedir. Bu yolla spor yapan, sporun insan ve toplum sağlığına olan faydalarını bilen, sporun gerektirdiği bilgi, beceri ve uygulama bilgisine sahip kişiler yetiştirilmektedir.

Programda yapılandırıcı eğitimin bilgi işlem yaklaşımı kullanıldığı belirtmiştir. Bu yaklaşım öğrenciyi bilgiyi bulma, değerlendirme gibi işlemleri kendi kendine yaparak, bilgiye ulaşmasında aktif rol oynamaktadır. Öğrenci böylece“bilgiyi hazır almak yerine, araştıran, sorgulayan, keşfeden, düşünen, eleştiren ve yaratıcılığını kullanan rollere" sahip olacaktır (MEB, 2012p, s.6-7). Kazandırılması beklenen diğer beceriler arasında araştırma ve bilgi teknolojilerini kullanma becerisi de yer almaktadır.

\section{T.C İnkılâp Tarihi ve Atatürkçülük Dersi Öğretim Programı ve Kılavuzu}

Bu programda öğrenciler, Atatürk, Atatürk devrimleri, tarihi olaylar, nutuk vb. konular öğrenmektedir. Tarihi mekânlara geziler yapılmalı, tarihi olayları öğrenebilecekleri farklı yazınsal türler tavsiye edilmeli (roman, biyografi, anı vb.) ifadeleri yer almaktadır (MEB, 2012q, s.7).

\section{Tarım Dersi (6-8. Sınıflar) Öğretim Programı ve Kılavuzu}

Program öğrencilerin ülke kaynakları, tarım ve uygulamalar konusunda bilgi sahibi olmalarını amaçlamaktadır (MEB, 2012r, s.4).

Öğretim programında öğrenci merkezli ve aktif öğrenme yaklaşımı benimsenmiştir. Yani öğrenci gerekli bilgileri bulmada aktif rol oynayarak araştırma yapar. Kazandırılması hedeflenen beceriler arasında araştırma ve bilgi teknolojilerini kullanma yer almaktadır (MEB, 2012r, s.7-9).

Genel olarak program öğrenciyi öğrenme süreci içinde aktif bir yer vererek kendisinin öğrenmesini ve bunu uygulayabilmesini sağlamaya çalışmaktadır. 


\section{Teknoloji ve Tasarım Dersi Öğretim Programı ve Kılavuzu}

Bu programda çocukların çağın gereklerine uygun bir şekilde bilgi ve becerilerle donatılarak geleceğe hazırlanmalarını sağlamak amaçlanmıştır.

“Kendisinin ve toplumun yarınını daha yaşanabilir hâle getirmek için sorunların farkına varan, çözümler üreten, yaratıcı ve hayal gücü gelişmiş, düşüncelerini kurgulayan ve ifade eden, öğrenmeyi öğrenen, sorgulayan, girişimci, değişim ve gelişime açık sorumluluk bilinci gelişmiş bireyler yetiştirmek" programın hedefleri arasındadır (MEB, 2012s, s.5).

\section{İlköğretim Trafik Güvenliği Dersi Öğretim Programı}

Erken yaşlarda edinilmesi gereken ve bu yaşlarda daha kolay öğrenilen trafik eğitimi aracılığıyla çocuklara, trafik bilinci verilirken, karşılaşabilecekleri problemler, uyulması gereken kurallar, yapılması ve yapılmaması gereken davranışlar konusunda bilgi ve beceri kazandırılmaya çalışılmaktadır. Programda "trafik kuralları konusunda duyarlı davranışlar sergileyecek bireylerin yetiştirilmesini sağlamak" amaçlanmıştır (MEB, 2012t, s.5).

\section{Türkçe Dersi (1-5. ve 6-8. Sınıflar) Öğretim Programı}

Bu programın amacı "Türkçeyi doğru, güzel ve etkili kullanan, eleştirel ve yaratıcı düşünebilen, bilgiyi kullanabilen, üretebilen, girişimci, kişisel ve sosyal değerlere önem veren" bireyler yetiştirmektir (MEB, 2012u, s.3).

Bilgi, iletişim ve teknolojinin her alanı etkilediği gibi eğitim sürecini de etkilediğini görmek mümkündür. Bu programla öğrencilerin "bilgiyi araştırma, keşfetme, yorumlama ve zihinde yapılandırma gibi becerileri kazanmaları hedeflenmektedir (MEB, $2012 u$, s.9). Türkçe dersi kapsamında tüm bu beceriler elbette okuma ile kazanılacaktır. Kütüphaneler aracılığıyla araştırma yapacak olan öğrenciler okuma sürecinde düşünme, anlama, sorgulama analiz yapma becerileri elde edeceklerdir. Ayrıca öğrencilerin okumaktan, öğrenmekten ve yazmaktan zevk alan; bilgi teknolojilerini kullanan; üreten ve geleceğine yön veren bireyler olmaları da beklenmektedir (MEB, 2012u, s.10-12).

Program kapsamında öğrenme alanları içinde yer alan okuma zihinsel, fizyolojik bir süreç olarak değerlendirilirken, okuma alışkanlığı kazandırmanın erken yaşlarda edindirilmesi gereken bir beceri olduğu vurgulanmıştır (MEB, 2012u, s.16).

\section{Vatandaşlık ve Demokrasi Eğitimi Dersi (8. Sınıf) Öğretim Programı}

Bu ders kapsamında öğrencilerin, demokrasi, insan hakları, vatandaşlık konularında bilgi sahibi olmaları hedeflenmektedir (MEB, 2012v, s.16). 
Demokrasi bilinci kazandırmada kütüphaneler çok önemli bir yere sahiptir. Demokrasi bilinçli, kendi tercihlerini sağlıklı bir şekilde yapabilen bireylerin rejimidir ve bu ancak okuyan, düşünen, sorgulayan ve dolayısıyla muhakeme yeteneği gelişmiş bireylerle mümkün olacaktır.

\section{Almanca (4-8.Sınıflar) Dersi Kurul Kararı ve Öğretim Programı}

Bu programda öğrencilerin Almancayı öğrenmeleri amaçlanmıştır. Bu dili kullanabilmeleri için gerekli bilgi ve beceriler yanında dinleme, okuma, konuşma ve yazma becerileri kazanmaları hedeflenmektedir.

Bir dilin kurallarıyla öğrenilmesinde en etkili yol okumaktan geçmektedir. Okuma ile öğrencilerin okuma becerisi ve alışkanlığı kazanması, o dile ait kelime dağarcığını geliştirmeleri istenmektedir (MEB, 2012w).

\section{Fransızca (4-8.Sınıflar) Dersi Kurul Kararı ve Öğretim Programı}

Bu programla öğrencilerin öğrenecekleri yeni bir dil aracılığıyla yeni kültürleri öğrenmeleri amaçlanmıştır. Kazanacakları dil becerileri sayesinde öğrenciler kendi kültürlerini de anlatabilecek düzeye gelmeleri hedeflenmektedir. Bu kapsamda okuma, yazma, dinleme ve konuşma becerileri kazanmaları amaçlanmıştır. Programda okuma ile dilin öğrenilmesi ve geliştirilmesinin önemi üzerinde durulmuştur (MEB, 2012y).

\section{Arapça (4-8.Sınıflar) Dersi Kurul Kararı ve Öğretim Programı}

Programda farklı bir dil öğrenmenin artık bir gereksinim olduğu ve önemi belirtilmiştir.

Yabancı dil öğrenmek isteyen kişilerin "hayat boyu öğrenmeyi ilke edinen" ve "düşünen, üreten, sorgulayan, sorunlara çözüm üreten" bireyler olmaları programın vizyonunu oluşturmaktadır (MEB, 2012z, s.4). Diğer dil öğrenimlerinde olduğu gibi Arapçanın öğrenilmesinde de okuma, yazma, konuşma ve dinleme becerileri edinmeleri amaçlanmıştır. Okuma becerisinin dilin öğreniminde önemli olduğu vurgulanmıştır.

Okuma becerisinin öğrencilere sağlayacağı faydalar arasında bilgi edinme, okuma alışkanlığı kazanma ve dili öğrenmek için gerekli söz dağarcığını geliştirme bulunmaktadır (MEB, 2012z, s.15).

\section{İlköğretim Programları Değerlendirme Tablosu}

Her bir öğretim programı amaç, kapsam, vizyon ve yöntem kısımları açısından yukarıda değerlendirilmiştir. Bu bölümde yukarıdaki kısımlara ek olarak örnek kazanım ve etkinlikler tabloları da incelenmek suretiyle Tablo I hazırlanmıştır. Dolayısıyla değerlendirmeye alınan 30 ilköğretim programı içinde her bir program bir bütün olarak incelenmiş ve program içinde geçen ifadeler taranarak, öğrencilerin araştırma, bilgi kaynaklarına yönlendirme, kütüphane kullanımına yönlendirme, internet ve medya araçlarına yönlendirme açısından değerlendirilerek tablo haline getirilmiştir. 
Tablo I. Program Değerlendirme Tablosu

\begin{tabular}{|c|c|c|c|c|c|}
\hline Dersler & Araştırma* & $\begin{array}{l}\text { Bilgi } \\
\text { kaynaklarına } \\
\text { yönlendirme* }\end{array}$ & $\begin{array}{l}\text { Kütüphaneye } \\
\text { yönlendirme }\end{array}$ & Internet $^{* * * *}$ & $\begin{array}{l}\text { Dergi, gazete, } \\
\text { televizyon }^{* * * * *}\end{array}$ \\
\hline Beden Eğitimi & $\checkmark$ & $\checkmark$ & $\checkmark$ & $\checkmark$ & $\checkmark$ \\
\hline Bilişim teknolojileri & $\checkmark$ & $\checkmark$ & $\checkmark$ & $\checkmark$ & $\checkmark$ \\
\hline $\begin{array}{l}\text { Din kültürü ve ahlak } \\
\text { bilgisi }\end{array}$ & $\checkmark$ & $\checkmark$ & & $\checkmark$ & $\checkmark$ \\
\hline Düşünme eğitimi & $\checkmark$ & $\checkmark$ & & $\checkmark$ & $\checkmark$ \\
\hline Fen ve teknoloji & $\checkmark$ & $\checkmark$ & $\checkmark$ & $\checkmark$ & $\checkmark$ \\
\hline Görsel sanatlar & $\checkmark$ & $\checkmark$ & $\checkmark$ & $\checkmark$ & $\checkmark$ \\
\hline Halk kültürü & $\checkmark$ & $\checkmark$ & $\checkmark$ & $\checkmark$ & $\checkmark$ \\
\hline Hayat bilgisi & $\checkmark$ & $\checkmark$ & $\checkmark$ & $\checkmark$ & $\checkmark$ \\
\hline İngilizce & $\checkmark$ & & & $\checkmark$ & \\
\hline Matematik & $\checkmark$ & $\checkmark$ & & $\checkmark$ & $\checkmark$ \\
\hline Medya okuryazarlığı & $\checkmark$ & $\checkmark$ & $\checkmark$ & $\checkmark$ & $\checkmark$ \\
\hline Müzik & $\checkmark$ & $\checkmark$ & & $\checkmark$ & $\checkmark$ \\
\hline Sanat etkinlikleri & $\checkmark$ & $\checkmark$ & $\checkmark$ & $\checkmark$ & $\checkmark$ \\
\hline Satranç & $\checkmark$ & $\checkmark$ & & $\checkmark$ & $\checkmark$ \\
\hline Sosyal bilgiler & $\checkmark$ & $\checkmark$ & $\checkmark$ & $\checkmark$ & \\
\hline Spor etkinlikleri & $\checkmark$ & $\checkmark$ & & & \\
\hline $\begin{array}{l}\text { T.C. İnkılap Tarihi ve } \\
\text { Atatürkçülük }\end{array}$ & $\checkmark$ & & & $\checkmark$ & \\
\hline Tarım & $\checkmark$ & & $\checkmark$ & $\checkmark$ & \\
\hline Teknoloji ve tasarım & $\checkmark$ & $\checkmark$ & & $\checkmark$ & \\
\hline Trafik güvenliği & $\checkmark$ & & & $\checkmark$ & $\checkmark$ \\
\hline Türkçe & $\checkmark$ & $\checkmark$ & $\checkmark$ & $\checkmark$ & $\checkmark$ \\
\hline $\begin{array}{l}\text { Vatandaşlık ve } \\
\text { demokrasi eğitimi } \\
\text { Almanca }\end{array}$ & $\checkmark$ & $\checkmark$ & & $\checkmark$ & $\checkmark$ \\
\hline \multicolumn{6}{|l|}{ Fransızca } \\
\hline \multicolumn{6}{|l|}{ Arapça } \\
\hline \multicolumn{6}{|c|}{$\begin{array}{l}\text { *Programda ders etkinlik örneklerinde geçen ifadelere baktığımızda öğrencilerin ünitelerdeki konulara göre } \\
\text { araştırma yapmaya yönlendirilmektedirler. Ünitede geçen ilgili konuda öğrencilerin fotoğraf, anı ya da genel } \\
\text { olarak bilgi toplayarak araştırma yapmaları istenmektedir. } \\
\text { ** Öğrencilerin ders içeriğive konusuna göre farklı kaynaklardan arama yapmaları istenir. Sözlük, ansiklopedi } \\
\text { ve kaynak kitaplarla araştırma yapmak için yönlendirildikleri bazı bilgi kaynaklarıdır. } \\
\text { *** Ders kapsamında elde etmeleri gereken bilgileri kütüphaneyi kullanarak elde edebileceklerini öğretmek } \\
\text { amacıyla kütüphanelerden faydalanabilecekleri ifade edilmiştir. } \\
\text { **** Öğrenciler araştırmalarında bilişim teknolojileri, veri tabanları gibi araştırma araçlarına yönlendirilir. } \\
\text { Bilgi teknolojilerini kullanır ifadesiyle bilgisayar, televizyon ve telefon kullanarak bilgiye ulaşmayı ifade eder. } \\
\text { ***** Dergi, gazete, video, cd, televizyon gibi bilgi teknolojileri ve medya araçları yani görsel ve yazılı basın } \\
\text { araçlarından araştırma yapmaları istenir. }\end{array}$} \\
\hline
\end{tabular}




\section{Sonuç ve Öneriler}

Çalışmamızda yer alan 30 ilköğretim programına ilişkin elde edilen bulgulara baktığımızda iki farklı değerlendirmenin söz konusu olduğu ortaya çıkmaktadır. Araştırmamızın yer aldığı ilk kısımlarda her bir ilköğretim programı amaç, kapsam, vizyon ve yöntem açılarından incelenerek teorik olarak adlandırabileceğimiz değerlendirmeler yapılmıştır. İkinci kısımda, yine her bir ilköğretim programına ilişkin pratik bilgiler doğrultusunda daha çok sınıf içi uygulamaları yansıtan kazanım ve etkinlik örnekleri incelenmiş, değerlendirilmiş ve sonuçlar tablo haline getirilmiştir. İlköğretime yönelik incelediğimiz her bir öğretim programı kendi içinde bir bütündür.

İlköğretim programlarında yer alan 30 ders için amaç, kapsam, vizyon, yöntem kısımlarına genel olarak baktığımızda öğrencilerin araştırmaya, bilgi kaynaklarına, kütüphaneye, internete ve medya kaynaklarına aynı oranda ve sıklıkta yönlendirilmedikleri saptanmıştır. Ders yapısı ve içeriğine göre amaç kapsam vizyon ve yöntem bazı farklılıklar gösterse de temelde her bir öğretim programı hedeflenen özel amaçlar yanında dersin kazandırmak istediği genel amaçlara da sahiptir. Programlarda öğrencilere kazandırılması hedeflenen "öğrenmeyi öğrenen, aktif ve katılımcı olmak" gibi ortak nitelikler bulunmaktadır. Sosyal Bilimler ve Türkçe derslerinin bu anlamda daha fazla yönlendirici ifadelere yer verdiklerini söyleyebiliriz.

Araştırmada ölçüt alınan ifadeler yanında, etkinlik örneklerinde öğrenciler bilgi iletişim teknolojilerini kullanır sözleriyle genel bir yönlendirme yapılmıştır. Burada görsel, işitsel, basılı, yazılı araçlar ifade edilmektedir. Hatta bazı ders konularında kütüphane yapı ve işleyişi örnek gösterilerek dolaylı bir yönlendirme yapılmaktadır. Örneğin Bilişim Teknolojileri dersinde öğrenciler okul kütüphanesine götürülerek kitap kayıtlarının bilgisayarda nasıl tutulduğunun gözlenmesi istenmiştir.

30 ilköğretim programının bütününde okuma, araştırma, kütüphane ve bilgi kaynaklarını kullanmaya ait yönlendirici ifadeler taranmıştır. Böylece okul ile kütüphane ilişkisinin öğretim programları aracılığıyla nasıl kurulduğunu anlamaya yönelik ayrıntılı incelemeler ve değerlendirmeler yapılmıştır. Tüm bulgular ışığında araştırmamızdan elde edilen sonuçları şu şekilde sıralayabiliriz:

$\diamond \quad$ Illköğretim ders programı içinde yer alması gereken okuma ve kütüphane kullanma alışkanlığı yanında araştırma ve bilgi teknolojilerini kullanma becerisi tüm programlarda aynı ağırlıkta yer verilmemiştir. Okul kütüphaneleri ve kütüphane kullanma alışkanlığına yönelik olarak yapılan yönlendirmelerin sayısı son derece azdır. Erken yaşlarda kazandırılması gereken bu alışkanlıklar tüm eğitim hayatını etkileyeceğinden gereken önemin gösterilmediği sonucuna varılmıştır.

$\diamond$ Öğretim programlarında Türkçe ve Sosyal Bilgiler dersleri diğerlerine oranla araştırmaya, bilgi kaynaklarına ve kütüphaneye yönlendirmeye daha fazla yer vermektedir. Ders kapsamında okuma, bilgiye ulaşma, bilgiyi kullanma gibi beceriler kazandırılmaya çalışılmaktadır. 
$\diamond$ Dil öğrenmeye ilişkin derslerde (Arapça, Almanca, İngilizce, Fransızca) araştırma, kütüphane ve bilgi kaynaklarına gönderme en olumsuz düzeydedir. Belirtilen bu durum, mümkün olduğunca çok okumayı ve uygulama yapmayı gerektiren dil öğrenimi açısından düşündürücü bir sonuç olmaktadır.

$\diamond \quad$ Öğretim programlarında yer alan amaçlar ve gerçekleştirilmesi beklenen hedefler etkinlik kısmında yeteri kadar ve aynı ağırlıkta yer almamaktadır.

Gerçekleştirdiğimiz çalışmalar, ilköğretim programlarının öğrencilerin araştırma, kütüphane kullanma ve çeşitli bilgi kaynaklarına yönlendirme etkinliklerine yer verdiğini saptaması açısından önemli sonuçlara ulaşmış görülmektedir. Bu sonucun önemi, çocukların ilköğretime başlar başlamaz okuma, kütüphane ve araştırma yapma gibi etkinliklerle resmen karşılaşacaklarının belirtilmesinde ortaya çıkmaktadır. Eğitim ve bilgi hizmetlerinde nesilleri etkileyen geniş kapsamlı beklentiler oluşmaktadır. Elde edilen sonuçlardan yola çıkarak, sadece birkaç temel yönlendirme ile değil, ilköğretim programlarının planlı ve sistemli bir şekilde geliştirilmesini hedefleyen önerilerimiz şunlardır:

$\diamond$ Tüm eğitim hayatının ve yaşam boyu sürecek olan öğrenme etkinliklerinin temelini teşkil edecek bilgi ve onu en güvenilir şekilde elde edeceğimiz yer olan kütüphane kullanımının erken yaşlarda kazandırıması gereken alışkanlık olduğu bilinen bir gerçektir. Bu noktadan hareketle, Türk milli eğitim sistemi başta olmak üzere ilköğretim programlarında okuma, kütüphane ve araştırma yapma gibi etkinlikler daha fazla yer almalı ve uygulamalar yapılmalıdır.

$\diamond$ Sadece Türkçe ve sosyal bilgiler dersi değil tüm ders içeriklerinde aynı oranda kütüphane kullanımı, bilgi kaynaklarının kullanımı, araştırma yapma konularında yönlendirici ve bilgilendirici etkinliklerin yer alması gerekmektedir. Eğitim sürecinin içinde aktif ve öğrenmeyi öğrenen bireyleri yaratmak ancak bu şekilde mümkün olacaktır.

$\diamond \quad$ Teknolojik kaynakları, araç ve gereçleri etkin olarak kullanacağını düşündüğümüz çocukların, bir başka deyişle yeni neslin bilgi kaynaklarından yoğun olarak yararlanacağı tahmin edilmektedir. Genç nüfusun yoğun olduğu Türkiye'de çocukluktan başlayarak, gençlerin ve yetişkinlerin bilgi kaynaklarına doğru ve güvenilir biçimde erişmesi büyük önem taşımaktadır. Bu nedenle bilgi okuryazarlığı eğitimi kadar medya okuryazarlığı eğitiminin de önemli olduğu unutulmaması gereken diğer bir noktadır. Tüm bu çalışmaların verimli olabilmesi için öğretim programları kapsamında değerlendirilmeli ve okul kütüphanelerinin kullanımıyla bütünleştirilmelidir.

$\diamond$ İlköğretim programlarının hazırlanması, uygulanması ve değerlendirilmesi aşamalarına konumuzla ilgili okuma, kütüphane, araştırma yapma ve yaptırma gibi alanlara özel önem verilmelidir. Kütüphanelerin öğretim programlarının etki alanını genişleteceği unutulmamalıdır. 
$\diamond$ Kongreler, konferanslar, çalıştaylar, seminerler, milli eğitim şuraları, geziler, yarışmalar, yayınlar, rehberler, yazarların imza günleri ve benzeri organizasyonlarla bütün öğretim programlarının başarıyla uygulanmasına ve geliştirilmesine hizmet eden çalışmalara öğrenci, öğretmen, veli, yetişkin olmak üzere her düzeyden katkıda bulunulmalıdır.

$\diamond$ Okul kütüphanecileri öğretim programlarıyla ilgili gelişmelere daima duyarlı olmalıdır.

$\diamond$ Eğitimin amaçlarını gerçekleştirmenin standartlara uygun, aktif ve gelişime açık okul kütüphanesi hizmetlerinin katkısıyla sağlanabileceği unutulmamalıdır. Ülkemizde sayılan bu özelliklere sahip okul kütüphanelerinin eksikliği bilinen bir gerçektir. Var olan okul kütüphaneleri uluslararası mesleki standartlara uygun biçimde güçlendirilerek, kütüphanesi olmayan okullara sayılan niteliklerde kütüphane kurarak, gelişmiş kütüphanelerin daha kaliteli hizmet anlayışını benimseyerek ve bütün kütüphanelerin deneyimlerini paylaşarak çalışmalarını sürdürmelidirler. Milli Eğitim Bakanlığı, okul yöneticileri, öğretmenler, öğrenciler, veliler, toplumsal kuruluşlar ve bütün bireyler sorumluluklarının bilincinde olarak eğitim sürecinde yer almalıdırlar. Okul kütüphanelerinin geliştirilmesi öğretim programlarına olumlu etkiler yapacaktır.

Kütüphaneciler ve eğitimciler çalışma alanlarını bütünleştirerek dikkatlerini bilgilenme, öğretim süreçleri ve yaşam boyu gelişim üzerine yoğunlaştırırlarsa, eğitim ve öğretim kişilere zorunlu ve kalıplaşmış bilgileri belli programlar çerçevesinde kazandırma aracı olmaktan çıkacaktır. Okulda öğrenilen bilgiyi yaşamla bütünleştirecektir. Yeni nesiller eğitimleri boyunca bilgiyi öğrenme, yaratma ve yaşamı zenginleştirme aracı olarak kullanabileceklerdir. Türkiye' de Milli Eğitim Bakanlığı'nın gerçek anlamda eğitimi gerçekleştirme amacıyla ilköğretim programlarında okul kütüphanelerine yer vermekle birlikte, okul kütüphanesi hizmetlerini geliştirmeye yönelik önlemler alması eğitim ve öğretim çalışmalarının hedeflerine ulaşmalarını sağlayacaktır.

\section{Kaynakça}

Callison, D. (1998). History of the research on issues related to school library media programs and services 1925-1995. K.H. Latrobe (Yay. Haz.). The emerging school library media center: historical issues and perspectives içinde (ss.91-136). Englewood: Libraries Unlimited.

Demirel, Ö. (2005). Eğitimde program geliştirme. Ankara: Pegem.

Dengiz, A.Ş. (2006). 2004 Illköğretim programı́nın okuma ve kütüphane kullanma alışkanlıkları açısından değerlendirilmesi. Yayınlanmamış yüksek lisans tezi, Hacettepe Üniversitesi, Ankara.

Ertürk, S. (1982). Eğitimde program geliştirme. Ankara: Meteksan.

Ertürk, S. (1997). Eğitimde program geliştirme. Ankara: Yelkentepe Yayınları.

Fasick, A. M. (2011). From boardbook to Facebook: children's services in an interactive age. Santa Barbara: Libraries Unlimited. 
Fidan, N. ve Erden, M. (1993). Eğitime giriş. Ankara: Meteksan.

Filiz, S.B. (2006). Eğitim bilimine giriş. (Çağatay Özdemir, Ed.). Ankara: Ekinoks.

Hançerlioğlu, O. (1982). Felsefe sözlüğü. İstanbul: Remzi Kitabevi.

IFLA/UNESCO (t.y.). Okul kütüphanesi bildirgesi. (İnci Önal, Çev.). 15 Haziran tarihinde http:// archive.ifla.org/VII/s11/pubs/slm-tr.pdf http://archive.ifla.org/VII/s11/pubs/slm-tr.pdf adresinden erişildi.

İlköğretim Kurumları Yönetmeliği. (2003). T.C. Resmi Gazete, 25212, 27 Ağustos 2003. 17 Haziran tarihinde http://mevzuat.meb.gov.tr/html/225_0.html adresinden erişilmiştir.

İlköğretim ve Eğitim Kanunu (1961) T.C. Resmi Gazete, 10705, 12 Ocak 1961. 14 Haziran tarihinde http://mevzuat.meb.gov.tr/html/24.html adresinden erişilmiştir.

İlköğretim ve Eğitim Kanunu (2012). Değişik: 30/3/2012 - 6287/1 md. 14 Haziran tarihinde http:// mevzuat.meb.gov.tr/html/24.html adresinden erişilmiştir.

Marquardt, L. ve Oberg, D. (Yay. Haz.). (2011). Global perspectives on school libraries: projects and practices. Berlin: De Gruyter Saur.

Milli Eğitim Temel Kanunu (1973). T.C. Resmi Gazete, 14574, 24 Haziran 1973. 14 Haziran 2012 tarihinde http://www.meb.gov.tr/mevzuat/liste.asp?ara=4\&Submit=Listele adresinden erişildi.

Milli Eğitim Temel Kanunu (1983). Değişik: 16/6/1983 - 2842/1 md. 14 Haziran 2012 tarihinde http:// www.meb.gov.tr/mevzuat/liste.asp?ara=4\&Submit=Listele adresinden erişildi.

Milli Eğitim Temel Kanunu (2012). Değişik: 30/3/2012 - 6287/8 ve 9 md. 14 Haziran 2012 tarihinde http://www.meb.gov.tr/mevzuat/liste.asp?ara=4\&Submit=Listele adresinden erişildi.

MEB (2012a). ilköğretim Beden Eğitimi Dersi (1-8 sınıflar) Öğretim Programı. Ankara: MEB.

MEB (2012b). İlköğretim Bilişim Teknolojileri Dersi (1-8. Sınıflar) Öğretim Programı. Ankara: MEB.

MEB (2012c). Illköğretim Din Kültürü ve Ahlâk Bilgisi Dersi (4-8. Sınıflar) Öğretim Programı. Ankara: MEB.

MEB (2012d). Illköğretim Düşünme Eğitimi Dersi (6-8.Sınıflar) Öğretim Programı. Ankara: MEB.

MEB (2012e). Illköğretim Fen ve Teknoloji Dersi (4-5 ve 6-8 Sınıflar) Öğretim Programı. Ankara: MEB.

MEB (2012f). Illköğretim Görsel Sanatlar Dersi (1-8.Sınıflar) Öğretim Programı ve Kılavuzu. Ankara: MEB.

MEB (2012g). İlköğretim Halk Kültürü Dersi (6-7 ve 8. Sınıflar) Öğretim Programı ve Kılavuzu. Ankara: MEB.

MEB (2012h). Illköğretim Hayat Bilgisi Dersi (1-3.Sınıflar) Öğretim Programı. Ankara:MEB.

MEB (2012i). İlköğretim Ingilizce Dersi(4-8.Sınıflar) Öğretim Programı ile Seçmeli İng. Dersi Öğretim Programı. Ankara: MEB.

MEB (2012j). İlköğretim Matematik Dersi (1-5. ve 6-8. Sınıflar) Öğretim Programı. Ankara: MEB

MEB (2012k). İlköğretim Medya Okuryazarlığı Dersi Öğretim Programı ve Kılavuzu. Ankara: MEB.

MEB (2012l). İlköğretim Müzik Dersi(1-8 Sınıflar) Öğretim Programı. Ankara: MEB.

MEB (2012m). illköğretim Sanat Etkinlikleri Dersi (1-8. Sınıflar) Öğretim Programı. Ankara: MEB. 
MEB (2012n). ilköğretim Satranç Dersi (1-8 Sınıflar) Öğretim Programı. Ankara: MEB.

MEB (20120). Ilköğretim Sosyal Bilgiler Dersi (4-5. ve 6-7. Sınıflar) Öğretim Programıve Kılavuzu. Ankara: MEB.

MEB (2012p). Illköğretim Spor Etkinlikleri Dersi (1-8 Sınıflar) Öğretim Programı. Ankara: MEB.

MEB (2012q). Illköğretim T.CInkılâp Tarihi ve Atatürkçülük Dersi Öğretim Programı ve Kılavuzu. Ankara: MEB.

MEB (2012r). İlköğretim Tarım Dersi (6-8. Sınıflar) Öğretim Programı ve Kılavuzu. Ankara: MEB.

MEB (2012s). Illköğretim Teknoloji ve Tasarım Dersi Öğretim Programı ve Kılavuzu. Ankara: MEB.

MEB (2012t). İlköğretim Trafik Güvenliği Dersi Öğretim Programı. Ankara: MEB.

MEB (2012u). Illköğretim Türkçe Dersi (1-5. ve 6-8. Sınıflar) Öğretim Programı. Ankara: MEB.

MEB (2012v). İlköğretim Vatandaşılk ve Demokrasi Eğitimi Dersi (8. Sınıf) Öğretim Programı. Ankara: MEB.

MEB (2012w). İlköğretim Almanca (4-8.Sınıflar) Dersi Kurul Kararı ve Öğretim Programı. Ankara: MEB. MEB (2012y). Illköğretim Fransızca (4-8.Sınıflar) Dersi Kurul Kararı ve Öğretim Programı. Ankara: MEB. MEB (2012z). Illköğretim Arapça (4-8.Sınıflar) Dersi Kurul Kararı ve Öğretim Programı. Ankara: MEB.

Okul Kütüphaneleri Yönetmeliği. (2001). T.C. Resmi Gazete, 24501, 22 Ağustos 2001. 15 Haziran tarihinde http://mevzuat.meb.gov.tr/html/2529_0.html adresinden erişilmiştir.

Önal, H.I. (1992). Bilgi gereksinimlerinin karşılanması ve okul kütüphaneleri. Yayınlanmamış doktora tezi. Hacettepe Üniversitesi, Ankara.

Önal, H.i. ( 2005). New developments on the Turkish school library science. Journal of Librarianship and Information Science, 37(3), 141-152.

Önal, H. İ. (2009). IFLA / UNESCO school library manifesto for creating one World: Germany, Iran and Turkey in comparative perspective. Libri, 59(1), 45-54.

Önal, H. İ. (2012). Building excellent libraries with and for children. Bon,I., Cranfield, A. ve Latimer, K. (Yay. Haz.). Designing library space for children içinde (s. 65-82). Berlin: De Gruyter Saur.

Soysal, Ö. (1969). Çağdaş eğitim ve Türkiye'de okul kütüphanesi. Ankara: Güven Matbaası.

Türkiye Cumhuriyeti .(1924). Tevhid-i Tedrisat Kanunu. Resmi Gazete, no. 430.

Woolls, B. (2008). The School library media manager. Westport: Libraries Unlimited.

Yılmaz, B. (2004). Türkiye'de eğitim politikası ve kütüphane. Ankara: Türk Kütüphaneciler Derneği. 